\title{
Kandungan Kolesterol Darah pada Berbagai Jenis Ayam Konsumsi
}

\author{
Reni Rakhmawati ${ }^{1 *}$ dan Mei Sulistyoningsih ${ }^{2}$ \\ 1,2 Universitas PGRI Semarang \\ *E-mail: rahmamashuri@yahoo.co.id
}

\begin{abstract}
Abstrak
Darah adalah salah satu parameter dari status kesehatan hewan karena darah mempunyai fungsi penting dalam pengaturan fisiologis tubuh (Bijanti et al., 2009). Kandungan kolesterol darah pada hewan akan mempengaruhi kandungan dari daging hewan tersebut. Penelitian ini bertujuan untuk mengetahui kandungan kolesterol darah pada berbagai jenis ayam konsumsi. Rancangan yang digunakan adalah Rancangan Acak Lengkap (RAL). Materi penelitian terdiri 4 perlakuan dengan 4 pengulangan. Menggunakan ayam broiler umur 5 minggu, ayam pejantan umur 8 minggu, ayam kampung umur 24 minggu dan ayam merah 96 minggu. Hasil penelitian ini menunjukan berpengaruh nyata $(P<0,05)$ terhadap kolesterol darah. Kandungan kolesterol darah pada berbagai jenis ayam konsumsi berpengaruh nyata dengan hasil presentase tertinggi pada P4 (ayam pejantan) dengan rerata 298,33 mg/dl dan hasil presentase terendah pada P3 (ayam kampung) dengan rerata 183,00 $\mathrm{mg} / \mathrm{dl}$.
\end{abstract}

Kata kunci: ayam, kandungan, kolesterol darah.

\section{PENDAHULUAN}

Kebutuhan protein hewani masyarakat sangat tinggi maka perlu dilakukan upaya peningkatan produktivitas ayam agar ayam yang dikonsumsi memiliki gizi yang tinggi. Peningkatan produktivitas ayam tidak cukup hanya perbaikan pakan dan manajemen pemeliharaan, tetapi perlu dilakukan peningkatan mutu genetiknya dengan mempertahankan sifat-sifat khas fisiologi tubuh ayam tersebut. Salah satu parameter fisiologis tubuh yang mencerminkan kondisi ternak unggas (ayam) adalah kolesterol darah.

Darah adalah salah satu parameter dari status kesehatan hewan karena darah mempunyai fungsi penting dalam pengaturan fisiologis tubuh (Bijanti et al., 2009). Fungsi darah secara umum berkaitan dengan transportasi komponen di dalam tubuh seperti nutrisi, oksigen, karbondioksida, metabolit, hormon, panas, dan imun tubuh sedangkan fungsi tambahan dari darah berkaitan dengan keseimbangan cairan dan pH tubuh (Ali et al., 2014). Kandungan kolesterol darah pada hewan akan mempengaruhi kandungan dari daging hewan tersebut.

Kolestrol darah adalah termasuk keluarga lemak yang disimpan dalam jaringan hati atau dinding pembuluh darah. Kolesterol berhubungan erat dengan keadaan aterosklerosis, dimana terdapat penimbunan bahan-bahan mengandung kolesterol pada dinding pembuluh darah yang menyebabkan penyakit jantung (Tillman,1986). Beberapa unsur-unsur lipid, kolesterol adalah yang paling sering di anggap sebagai satu-satunya lipid yang terlibat dalam hubungan insiden aterosklerosis dan penyakit jantung koroner..

\section{METODE/EKSPERIMEN}

Penelitian ini menggunakan Rancangan Acak Lengkap (RAL). Subjek dalam penelitian ini adalah ayam yang biasanya dikonsumsi masyarakat dengan menggunakan sampel ayam broiler umur 5 minggu, ayam pejantan umur 8 minggu, ayam kampung umur 24 minggu, dan ayam merah 96 minggu. Penelitian ini terdiri 4 perlakuan dengan 4 pengulangan. Setiap jenis ayam diambil 4 ekor ayam sebagai ulangan sehingga jumlah total sampel penelitian semuanya 16 ekor ayam. Variabel dependen yaitu kolesterol darah. Data yang diperoleh dianalisis dengan Analisis of Variance (ANAVA), dilanjutkan dengan Uji Jarak Ganda Duncan (UJGD). 


\section{HASIL DAN PEMBAHASAN}

Hasil

Data hasil penelitian pada berbagai jenis ayam konsumsi adalah sebagai berikut :

\begin{tabular}{|c|c|c|c|c|c|}
\hline \multirow[t]{2}{*}{ Perlakuan } & \multicolumn{3}{|c|}{ Ulangan Ke- } & \multirow{2}{*}{$\begin{array}{l}\text { Jumlah } \\
\text { Perlakuan } \\
\text { (T) }\end{array}$} & \multirow{2}{*}{$\begin{array}{l}\text { Rataan } \\
\text { perlakuan }\end{array}$} \\
\hline & 1 & $\mathrm{mg} / \mathrm{dl}$ & 3 & & \\
\hline P1 (Ayam Broiler) & 366 & 188 & 222 & 776 & $258,67^{a}$ \\
\hline P2 (Ayam Merah) & 206 & 214 & 135 & 555 & $185,00^{b}$ \\
\hline P3 (Ayam Kampung) & 189 & 181 & 179 & 549 & $183,00^{b}$ \\
\hline P4 (Ayam Pejantan) & 270 & 287 & 338 & 895 & $298,33^{a}$ \\
\hline Jumlah Ulangan & 1031 & 870 & 874 & 2775 & \\
\hline Rataan Umum & & & & & 231,25 \\
\hline
\end{tabular}

Superskrip pada tabel di atas, bahwa pada kolom yang sama dengan baris berbeda menunjukkan beda nyata $(P<0,05)$.

\section{Pembahasan}

Hasil dari analisis menunjukkan bahwa presentase kolesterol darah berbeda nyata atau signifikan pada keempat jenis ayam yaitu ayam broiler, ayam merah, ayam kampung dan ayam pejantan. Rerata presentase kolesterol darah pada berbagai jenis ayam berturut-turut yaitu P4 (298,33 mg/dl) pada ayam pejantan, P1 (258,67 mg/dl) pada ayam broiler, P2 (185,00 mg/dl) pada ayam merah dan kemudian P3 (183,00 mg/dl) pada ayam kampung.

Kadar kolesterol darah normal ayam berkisar antara 125-200 mg/dl (Mangisah, 2003). Hasil rerata presentase kolesterol darah pada berbagai jenis ayam konsumsi yang paling tinggi yaitu P4 (298,33 mg/dl) dan P1 (258,67 mg/dl). Menurut (Wahju,1997) pada ayam pejantan umur 6 minggu memiliki kandungan lemak yang digunakan untuk pertumbuhan, pada penelitian menggunakan ayam pejantan yang berumur 8 minggu, oleh karena itu ayam sudah tidak dalam masa pertumbuhan. Lemak didalam tubuh ayam tidak digunakan oleh karena itu kandungan kolesterol darah yang terdapat dalam ayam pejantan lebih tinggi. Pada ayam broiler juga memiliki kandungan kolesterol darah yang tinggi dapat dilihat dari karakteristik ayam broiler sendiri menurut Suprijatna et al. (2008) yaitu bersifat tenang, bentuk tubuh besar, pertumbuhan ayam cepat, bulu merapat ke tubuh ternak, kulit ayam putih dan produksi telur yang rendah, dengan karakteristik broiler yang dapat bertumbuh dengan cpeat, maka ayam akan mengkonsumsi pakan lebih banyak sehingga dapat mempengaruhi presentase lemak dalam tubuhnya. Metabolisme kolesterol di dalam tubuh ayam akan meningkat dengan di dukungnya pakan yang berpotensi meningkatkan kandungan kolesterol dalam tubuh ayam, ditambah dengan kebutuhan nutrisi ayam yang terus meningkat maka pemberian pakan akan ditingkatkan setiap minggunya. Lemak yang masuk kedalam tubuh ayam akan di uraikan menjadi trigliserida, kolesterol, asam lemak, dan fosfolipid. Turunan-turunan lemak tersebut memiliki sifat-sifat larut didalam cairan tubuh seperti darah, sehingga pada proses metabolisme kolesterol akan bekerja sama dengan protein membentuk partikel lipoprotein yang larut didalam tubuh. Lipid umumnya bersifat hidrofobik sehingga dibutuhkan kerja sama dengan suatu pelarut yaitu apoprotein sehingga dihasilkan senyawa lipoprotein (Jim,2013). Kolesterol yang tinggi di dalam tubuh ayam akan semakin meningkat karena asupan protein yang terus meningkat sehingga dalam proses penguraiannya semakin tinggi asupan protein maka semakin tinggi pula kolesterol yang akan bekerjasama membentuk lipoprotein tersebut, sehingga semakin tingginya kolesterol yang akan larut kedalam cairan tubuh ayam seperti darah. Menurut (Almatsier 2006) Kolesterol bila terdapat dalam jumlah banyak dalam darah dapat membentuk endapan pada dinding pembuluh darah sehingga menyebabkan penyempitan yang disebut aterosklerosis. Federal dietary guidelines merekomendasikan untuk membatasi asupan kolesterol kurang dari $300 \mathrm{mg}$ per hari (Samaha, et al, 2003).

Kolesterol darah yang termasuk ke dalam kadar normal yaitu P2 (185,00 mg/dl) pada ayam merah dan P3 (183,00 mg/dl) pada ayam kampung. Sesuai dengan pendapat (Mangisah, 2003) Kadar kolesterol darah normal ayam berkisar antara 125-200 mg/dl. Hasil kadar kolesterol tersebut 
disebabkan karena pakan yang mengandung serat yang tinggi. Pernyataan tersebut di dukung oleh Almatsier (2004) bahwa konsumsi serat makanan mempunyai hubungan negatif dengan kolesterol darah. Pengaruh serat makanan ini dikaitkan dengan metabolisme asam empedu disintesis dalam hari dari kolesterol, disekresi kedalam empedu dan biasanya kembali ke hati melalui reabsorbsi dalam usus halus. Serat makanan diduga menghalangi siklus ini dengan menyerap asam empedu sehingga perlu diganti dengan pembuatan asam empedu baru dari kolesterol persediaan. Penurunan kolesterol diduga melalui proses ini. Murray (2003) dan Muwarni (2010) menambahkan bahwa salah satu faktor yang mempengaruhi penurunan kolesterol adalah penggunaan kolesterol untuk sintesis senyawa steroid lainnya, seperti hormon atau asam empedu dihati. Bahan pakan mengandung cukup serat, sebagian garam empedu akan berikatan dengan serat yang kemudian dikeluarkan melalui tinja sehingga penyerapan kembali garam empedu dari usus halus dan kembali ke hati menjadi lebih rendah dan kadar kolesterol hati berkurang. Kolesterol terbentuk secara alamiah, dari segi ilmu kimia, kolesterol merupakan senyawa kompleks yang dihasilkan oleh tubuh dengan bermacam-macam fungsi, antara lain untuk membuat hormone seks, hormone korteks adrenal, vitamin D, dan untuk membuat garam empedu yang membantu usus untuk menyerap lemak, jika takaranya pas atau normal, kolesterol adalah lemak yang berperan penting dalam tubuh (Sri Nilawati dkk, 2008).

\section{PENUTUP}

Hasil penelitian ini menunjukan berpengaruh nyata $(P<0,05)$ terhadap kolesterol darah. Kandungan kolesterol darah pada berbagai jenis ayam konsumsi berpengaruh nyata dengan hasil presentase tertinggi pada P4 (ayam pejantan) dengan rerata $298,33 \mathrm{mg} / \mathrm{dl}$ dan hasil presentase terendah pada P3 (ayam kampung) dengan rerata 183,00 mg/dl.

\section{DAFTAR PUSTAKA}

Ali, A. S., Ismoyowati, I., \& Indrasanti, D. (2014). Jumlah eritrosit, kadar hemoglobin dan hematokrit pada berbagai jenis itik lokal terhadap penambahan probiotik dalam ransum. Jurnal IImiah Peternakan, 1(3): 1001-1013.

Almatsier, S. (2006). Prinsip Dasar IImu Gizi. Jakarta: Gramedia Pustaka Utama.

Bijanti, R., W. Sri \& M. G. A. Yuliyani. (2009). Suplementasi Probiotik Pada Pakan Ayam Komersial Terhadap Produk Metabolik Dalam Darah Ayam. Jurnal Penelitian Med. Eksata, 3(8), 178-184.

Jim, E.L. (2013). Metabolisme lipoprotein. Bagian Kardiologi dan Kedokteran Vaskular Fakultas Kedokteran Universitas Sam Ratulangi Manado. Jurnal Biomedik (JBM), 5(3), 149-156.

Koswara, S. (2009). Teknologi Praktis Pengolahan Daging. Tersedia pada: www. Ebookpangan.com. Diakses pada pukul 2 Februari 2019. 4-10.

Mangisah, I. 2003. Pemanfaatan Kunyit (Curcuma Domestica) dan Temulawak (Curcuma Xanthorrizha Roxb) Upaya Menurunkan Kadar Kolesterol Daging Ayam Broiler. Jurnal Litbang Provinsi Jawa Tengah, 1(2), 96-101.

Murray, K. Robert, K. Daryl, A. M. Peter, W. R. Victor. (2003). Biokimia Harper Edisi 25. EGC.Jakarta.

Murwani, R. (2010). Broiler Modern. Semarang: Widya Karya.

Samaha, F. F., Iqbal, N., Seshadri, P., Chicano, K. L., Daily, D. A., McGrory, J., ... \& Stern, L. (2003). A low-carbohydrate as compared with a low-fat diet in severe obesity. New England Journal of 
34 | Titian IImu: Jurnal IImiah Multi Sciences Vol. 12 No. 1, Januari 2020

Medicine, 348(21), 2074-2081.

Sri, N. (2008). Care Your Self Kolesterol. Jakarta: Penebar Plus.

Suprijatna, E., Atmomarsono dan Kartasudjana. (2008). IImu Dasar Ternak Unggas. Jakarta: Penebar Swadaya.

Tillman, A. D., H. Hartadi, S. Reksohadiprojo, S. Prawirokusumo, \& S. Lebdosoekojo. (1986). IImu Makanan Ternak Dasar. Yogyakarta: Gadjah Mada University Press.

Wahju, J. (1997). IImu Nutrisi Unggas. Yogyakarta: Gadjah Mada University Press. 